ISEC2004-65093

\title{
ANALYSIS, DESIGN, AND PRELIMINARY TESTING OF SOLAR CHIMNEY FOR RESIDENTIAL AIR-CONDITIONING APPLICATIONS
}

\author{
Gang Wang \\ Bing Chen \\ Mingsheng Liu \\ Joerg Henkel \\ University of Nebraska - Lincoln \\ 1110 South 67th Street \\ Omaha, NE 68182
}

\author{
Stephan Raulin \\ Berliner Energy Agency \\ Holteistr.28 \\ 10245 Berlin, Germany
}

\begin{abstract}
A solar chimney is designed and tested to pump outside air through an underground cooling tube during summer for building cooling. Both theoretical analysis and experimental results show that the solar chimney can be used to power the underground cooling system during daytime without use of electricity. This paper presents the theoretical design principals of the solar chimney, detailed experimental facilities, and the experiments results. The impacts of other related parameters, such as building tightness and tube design on the system airflow are also discussed in the paper.
\end{abstract}

\section{INTRODUCTION}

A motor-driven compressor and a motor-driven fan are normally used in residential air conditioning systems [1]. Both of them consume electricity. Electricity is the primary power for building cooling. The electricity bill may be several times higher during summer months due to the electricity consumption of the building cooling system. The electrical motor makes noise. The heat rejected to the outside pollutes the environment as well.

Renewable energy, such as solar and geothermal energy, may provide solutions to our modern society problems. The geothermal energy may be used to provide cooling to building without use of electrical compressor. In fact underground soil temperature is much closed to supply air temperature for the building cooling. For example, the average soil temperature is about $12{ }^{\circ} \mathrm{C}\left(53{ }^{\circ} \mathrm{F}\right)$ while the cooling design outside air temperature is about $33^{\circ} \mathrm{C}\left(92^{\circ} \mathrm{F}\right)$ in Omaha, Nebraska [2, 3]. To use underground soil as the cooling source, a cooling tube can be buried underground as a soil-air heat exchanger. The air is cooled down when it passes through the tube. A theoretical model of the cooling tube thermal performance was developed and tested using the small scale cooling tube in the University of Nebraska in 1983 [4, 5]. In 1990, a $57 \mathrm{~m}$ (188 ft) long full scale cooling tube with a diameter of $0.457 \mathrm{~m}$ (18 inch) was installed and the thermal performance was evaluated in the Passive Solar Energy Research Test Facility of the University of Nebraska. An axial fan was installed at outlet of the tube to draft warm outside air through the cooling tube. The measurement shows that the cooling capacity of the cooling tube can reach to $5 \mathrm{~kW}(18,000 \mathrm{Btu} / \mathrm{h})$ with an airflow of 0.76 $\mathrm{m}^{3} / \mathrm{s}(1,600 \mathrm{CFM})$.

On the other hand, solar energy may be used to replace the electrical fan power. The total solar irradiation normal to the sun's rays is up to $30 \mathrm{MJ} /$ day. $\mathrm{m}^{2}\left(2,600 \mathrm{Btu} /\right.$ day. $\left.\mathrm{ft}^{2}\right)$ during summer [6]. Solar cookers have been developed to cook food and simple reflector cookers can offer the equivalent of a $500 \mathrm{~W}$ (1700Btu/h) hot plate in bright sun [7]. Solar energy is also used for space heating and cooling, domestic water heating, power generation, distillation, and process heating through solar collector [6]. A $50 \mathrm{~kW}$ demonstration solar chimney plant with a 195-meter (656-foot) high chimney and a 240 -meter (800-foot) diameter solar collector has been built in Spain. The solar collector warms up the ambient air and the warm air generates draft by the chimney, finally the air drives the turbine to produce electricity. After the demonstration, one $200 \mathrm{MW}$ full scale solar chimney plant has been scheduled to be built in Australia in 2006. Obviously, the solar chimney can generate enough draft for the air conditioning system.

An electricity energy free air conditioning system, solar chimney driven earth tube cooling system, was created by integrating the cooling tube and the solar chimney. This paper focuses on the contribution of the solar chimney to the cooling tube system. The paper presents the theoretical airflow model and design principals of the solar chimney, detailed experiments facilities, and the experiments results. 


\section{NOMENCLATURE}

$A_{s c} \quad$ surface area of solar collector that receives solar radiation, $\mathrm{m}^{2}$;

c flow coefficient of envelope air leakage, $\mathrm{m}^{3} / \mathrm{s} \cdot \mathrm{Pa}^{\mathrm{n}}$;

$c_{c}$ pressure loss coefficient of fittings through solar collector and chimney;

$c_{t} \quad$ pressure loss coefficient of fittings though cooling tube;

$C_{p} \quad$ air constant pressure specific heat, $\mathrm{J} / \mathrm{kg} \cdot{ }^{\circ} \mathrm{C}$;

$d_{c}$ diameter of chimney, $\mathrm{m}$;

$d_{t} \quad$ diameter of cooling tube, $\mathrm{m}$;

$D_{a c} \quad$ chimney available draft, $\mathrm{Pa}$;

$D_{t c} \quad$ chimney theoretical draft, $\mathrm{Pa}$;

$D_{t r} \quad$ room air stack affect (negative value), $\mathrm{Pa}$;

$D_{t t} \quad$ cooling tube stack affect (negative value), Pa;

$f_{c} \quad$ friction factor through chimney;

$f_{t} \quad$ friction factor through cooling tube;

$g$ gravitation acceleration, $9.8 \mathrm{~m} / \mathrm{s}^{2}$;

$H_{c} \quad$ chimney height above collector inlet, m;

$H_{t} \quad$ depth of cooling tube below tube outlet, m;

$H_{r}$ distance between cooling tube outlet and collector inlet, $\mathrm{m}$;

$I_{s} \quad$ solar irradiation of solar collector, $\mathrm{W} / \mathrm{m}^{2}$;

$L_{c} \quad$ duct length of solar chimney, m;

$L_{t} \quad$ cooling tube length, $\mathrm{m}$;

$n \quad$ exponent for envelope air leakage, $0.4<\mathrm{n}<1.0$;

$Q_{c} \quad$ chimney ventilation airflow, $\mathrm{m}^{3} / \mathrm{s}$;

$Q_{i} \quad$ infiltration airflow through envelopes, $\mathrm{m}^{3} / \mathrm{s}$;

$Q_{t} \quad$ underground cooling tube airflow, $\mathrm{m}^{3} / \mathrm{s}$;

$T_{c} \quad$ chimney air temperature or collector outlet air temperature, ${ }^{\circ} \mathrm{C}$;

$T_{o} \quad$ outside air temperature, ${ }^{\circ} \mathrm{C}$;

$T_{r}$ room air temperature or collector inlet air temperature, ${ }^{\circ} \mathrm{C}$;

$T_{t} \quad$ cooling tube supply air temperature, ${ }^{\circ} \mathrm{C}$;

$U_{L} \quad$ surface heat loss coefficient of solar collector, $\mathrm{W} / \mathrm{m}^{2} .{ }^{\circ} \mathrm{C}$;

$V_{c} \quad$ air velocity inside chimney, $\mathrm{m} / \mathrm{s}$;

$V_{t} \quad$ air velocity inside cooling tube, $\mathrm{m} / \mathrm{s}$;

$\alpha \quad$ solar radiation absorptance of solar collector;

$\Delta P_{c} \quad$ solar chimney pressure loss, $\mathrm{Pa}$;

$\Delta P_{i} \quad$ pressure difference cross envelopes, $\mathrm{Pa}$;

$\Delta P_{t} \quad$ cooling tube pressure loss, $\mathrm{Pa}$

$\Delta P_{s y s}$ cooling tube system required draft, which includes pressure loss and negative stack affect, $\mathrm{Pa}$;

$\rho_{c} \quad$ chimney air density, $\mathrm{kg} / \mathrm{m}^{3}$;

$\rho_{t} \quad$ air density at the outlet of cooling tube, $\mathrm{kg} / \mathrm{m}^{3}$;

$\rho_{o} \quad$ outside air density, $\mathrm{kg} / \mathrm{m}^{3}$;

$\rho_{r} \quad$ room air density, $\mathrm{kg} / \mathrm{m}^{3}$.

\section{SYSTEM AIRFLOW MODEL}

Figure 1 presents the cooling tube and solar chimney system. A cooling tube is buried underground and absorbs cooling from low temperature soil. The outside air flows through the tube to bring cooling from the soil to building and maintain comfort room temperature during summer. A chimney is installed to draw the air through the tube. The room air is heated up in the collector by the solar energy before entering the chimney, then the hot air generates the draft in the chimney, finally the chimney draft forms air ventilation in the cooling tube and solar chimney system.

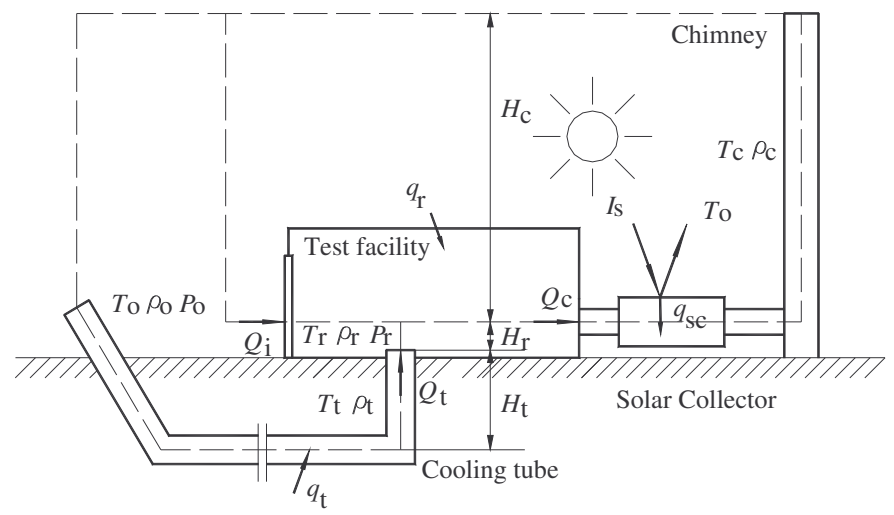

Figure 1: Cooling tube and solar chimney system schematic

The solar collector is the key part of the system. The air temperature leaving the solar collector under different ventilation airflows can be obtained based on the heat balance when the collector size and solar irradiation are given [6].

$$
I_{s} \alpha A_{s c}=U_{L}\left(\frac{T_{r}+T_{c}}{2}-T_{o}\right) A_{s c}+\rho_{r} Q_{c} C_{p}\left(T_{c}-T_{r}\right)
$$

Assuming that the air temperature inside of the chimney is the same as the discharge air temperature of the solar collector, the chimney theoretical draft can be calculated by the following formula [8]:

$$
D_{t c}=\left(\rho_{O}-\rho_{c}\right) g H_{c}
$$

Part of the chimney theoretical draft is consumed by the chimney itself. The chimney pressure loss is obtained by Darcy-Weisbach Equation [9].

$$
\begin{aligned}
\Delta P_{c} & =\left(\sum c_{c}+f_{c} \frac{L_{c}}{d_{c}}\right) \cdot \frac{\rho_{c} \cdot V_{c}^{2}}{2} \\
& =\left(\sum c_{c}+f_{c} \frac{L_{c}}{d_{c}}\right) \cdot \rho_{c} \cdot \frac{1}{2} \cdot\left(\frac{4 Q_{c}}{\pi \cdot d_{c}^{2}}\right)^{2}
\end{aligned}
$$

The chimney available draft is equal to the chimney theoretical draft minus the chimney pressure loss [8].

$$
\begin{aligned}
& D_{a c}=D_{t c}-\Delta P_{c} \\
& =\left(\rho_{O}-\rho_{c}\right) g H_{c}-\left(\sum c_{c}+f_{c} \frac{L_{c}}{d_{c}}\right) \cdot \rho_{c} \cdot \frac{1}{2} \cdot\left(\frac{4 Q_{c}}{\pi \cdot d_{c}^{2}}\right)^{2}
\end{aligned}
$$

Increasing the solar collector surface area and the chimney height and diameter can generate more chimney available draft. For given solar collector and chimney, the draft mainly 
depends on transient solar radiation. Therefore, the solar chimney system has a time dependent ventilation pattern.

Solar available draft makes the room under negative pressure and ventilates the room. According to the fluid dynamics, both pressure balance and airflow balance are used to develop the airflow model in the system.

\section{Pressure balance}

The chimney draft is not only balanced with the cooling tube pressure loss, but also balanced with the stack effect in the upward cooling tube or the room, which is normally ignored in the mechanical ventilation system.

The cooling tube pressure loss is by Darcy-Weisbach Equation [9].

$$
\begin{aligned}
\Delta P_{t} & =\left(\sum c_{t}+f_{t} \frac{L_{t}}{d_{t}}\right) \cdot \frac{\rho_{t} \cdot V_{t}^{2}}{2} \\
& =\left(\sum c_{t}+f_{t} \frac{L_{t}}{d_{t}}\right) \cdot \rho_{t} \cdot \frac{1}{2} \cdot\left(\frac{4 Q_{t}}{\pi \cdot d_{t}^{2}}\right)^{2}
\end{aligned}
$$

Since both the air in upward cooling tube and in room is colder than the ambient air, it means that the cooling tube and room have a negative stack affect. In other words, the chimney available draft should overcome the cooling tube pressure loss as well as the negative stack affect in the upward cooling tube and in the room air between the outlet of the cooling tube and the inlet of the solar collector.

Some assumptions are used in the thermal gravity affect calculation. The air temperature change in the relative short vertical cooling tube is ignored. The room temperature difference between the cooling tube outlet and the solar collector inlet is also ignored. So the stack affect in the cooling tube and the room can be expressed as:

$$
\begin{aligned}
& D_{t r}=\left(\rho_{O}-\rho_{r}\right) g H_{r}<0 \\
& D_{t t}=\left(\rho_{O}-\rho_{t}\right) g H_{t}<0
\end{aligned}
$$

The sum of the tube pressure loss $\left(\Delta P_{t}\right)$ and the negative pressures $\left(-D_{t r}\right.$ and $\left.-D_{t t}\right)$ can be defined as the cooling tube required draft.

$$
\begin{aligned}
\Delta P_{s y s}= & \Delta P_{t}-D_{t r}-D_{t t} \\
= & \left(\sum c_{t}+f_{t} \frac{L_{t}}{d_{t}}\right) \cdot \rho_{t} \cdot \frac{1}{2} \cdot\left(\frac{4 Q_{t}}{\pi \cdot d_{t}^{2}}\right)^{2} \\
& -\left(\rho_{O}-\rho_{r}\right) g H_{r}-\left(\rho_{O}-\rho_{t}\right) g H_{t}
\end{aligned}
$$

Therefore, based on the pressure balance, the chimney available chimney can be expressed as:

$$
D_{a c}=\Delta P_{s y s}
$$

The negative indoor pressure does not only suck the outside air through the cooling tube but also causes air infiltration through the envelopes, such as windows and doors.
The air infiltration airflow under a given pressure difference is obtained by the power law equation [10]. The c and $n$ values depend on the envelope tightness and can be obtained by the measurement.

$$
Q_{i}=c \cdot \Delta P_{i}^{n}
$$

Eq. (10) can also be rewritten as:

$$
\Delta P_{i}=\left(\frac{Q_{i}}{c}\right)^{\frac{1}{n}}
$$

The chimney available draft is balanced with the pressure difference cross envelope.

$$
D_{a c}=\Delta P_{i}
$$

\section{Airflow balance}

Due to the infiltration, the chimney airflow is always higher than the cooling tube airflow. Ignoring the infiltration will cause big error for the loosely constructed building.

Based on the mass conservation in the room, the chimney airflow should be balanced with the supply airflow through the cooling tube and the infiltration through envelopes if the density changes are ignored.

$$
Q_{c}=Q_{t}+Q_{i}
$$

For the complete theoretical model for the solar chimney cooling tube system, the room heat balance equation and the cooling tube balance equation need to be developed in order to obtain the room temperature and the cooling tube temperature under any outside and solar radiation conditions.

Since the paper focuses on the impact of the solar chimney on the airflow model, the cooling tube supply air temperature and the room temperature is treated as given parameters.

With these simplifications, for the given solar collector, chimney and cooling tube, the chimney ventilation airflow $\left(Q_{c}\right)$, the cooling tube airflow $\left(Q_{t}\right)$ and the infiltration airflow $\left(Q_{i}\right)$ under different outside and solar radiation conditions can be obtained by solving two pressure balance equations, Eqs. (8) and (12), and one airflow balance equation, Eq. (13).

\section{SYSTEM DESIGN}

The cooling tube and solar chimney system design includes the cooling tube design and the solar chimney design.

The cooling tube design includes the tube diameter, length and buried depth. As mentioned previously, the paper only focuses on developing the solar chimney airflow model, so the cooling tube is treated as given.

The solar chimney design includes the solar collector size and the chimney height and diameter. The solar chimney should have enough draft to overcome the cooling tube pressure loss and the negative thermal gravity affect under the design ventilation airflow. 
The equations for the chimney airflow model are used in the solar chimney design. The solar chimney design process includes:

\section{Required solar chimney available draft}

The solar chimney should provide enough draft to overcome the cooling tube pressure loss and negative thermal gravity affect. The system required draft $\left(\Delta P_{s y s}\right)$ or the chimney available draft $\left(D_{c a}\right.$ ) can be calculated using Eq. (8) based on the cooling tube diameter, length, fitting type and required airflow as well as the temperatures distribution.

\section{Solar chimney ventilation airflow}

The chimney ventilation airflow $\left(Q_{c}\right)$ is balanced with the cooling tube airflow $\left(Q_{t}\right)$ and the envelope infiltration airflow ( $Q_{i}$ ) based on Eq. (13). The infiltration airflow can be obtained from the chimney available draft using Eq. (10).

\section{Chimney height, size and air temperature}

As mentioned previously, the tall and big chimney has the high available draft under same chimney air temperature. In other words, the required chimney air temperature will be low and the solar collector size will be small for the tall and big chimney. Since the solar collector size is limited by the space, the tall and big chimney is the best choice. Meanwhile, the chimney height and size selection should consider the chimney strength, stability, cost and the surrounding landscape. For selected chimney height and diameter, the required chimney air density $\left(\rho_{c}\right)$ can be obtained by Eq. (4) using the chimney available draft $\left(D_{c a}\right)$ and the chimney ventilation airflow $\left(Q_{c}\right)$. Finally, the chimney air temperature $\left(T_{c}\right)$ is calculated from the density.

\section{Solar collector size}

The solar collector absorbing area $\left(A_{s c}\right)$ is determined based on required the chimney air temperature and chimney flow under local solar radiation and climate information using Eq. (1).

The chimney available draft is affected by the chimney height and diameter as well as the solar collector size. The high chimney available draft can be obtained by increasing one of these three parameters. However, all adjustments are limited by material and construction cost, installation space, and structure strength and stability. The coordination among these parameters is necessary in the solar chimney design.

A solar chimney was designed to replace the original electrical fan for the existing cooling tube system in Passive Solar Energy Research Test Facility of University of Nebraska. The test facility is a one story house ( 5 by $20 \mathrm{~m}$ or 16 by 64 feet) designed to investigate alternative heating and cooling experiments and their potential for commercial and residential use. The room's large south window front and the concrete slab create a high cooling load for the summer season. The 0.457 meter ( $1.5 \mathrm{feet})$ diameter 57 meter $(188 \mathrm{ft})$ long culvert tube has been buried at a depth of 3 meter (10 feet). The inlet of the tube is 0.6 meter ( 2 feet) above the floor inside the building. The cooling tube enters the Solar Site from the south side and runs southeast to northwest.

The building infiltration model has been tested. The measured air exchange rate in the test facility is about 2.25 air changes per hour $(\mathrm{ACH})$ under an indoor pressure of $50 \mathrm{~Pa}(0.2$ inch of water). The typical infiltration rate in housing in North America changes from about 0.2 ACH to 2.0 ACH [10]. The test shows that the building envelopes were not sealed well. The air infiltration of the building is correlated with the differential pressure across the envelope by the following equation, which was experimentally determined using the blower door test.

$$
Q_{i}=0.011 \cdot \Delta P_{i}^{0.7}
$$

To test the cooling tube thermal performance in the test facility, the original mechanical ventilation rate is $0.76 \mathrm{~m}^{3} / \mathrm{s}$ (1,600 CFM). However, it is hard for single solar chimney to generate that ventilation rate. For the experiment purpose, 0.12 $\mathrm{m}^{3} / \mathrm{s}$ (250 CFM) is selected to design the solar chimney system. The anticipated cooling tube air temperature is $17^{\circ} \mathrm{C}\left(63{ }^{\circ} \mathrm{F}\right)$ and the anticipated room temperature is $30^{\circ} \mathrm{C}\left(86^{\circ} \mathrm{F}\right)$ when the outside air temperature is $34^{\circ} \mathrm{C}(94 \mathrm{~F})$.

Combining the cooling tube pressure loss and the stack affect, the available chimney draft needs to be $5 \mathrm{~Pa}(0.020$ inch of water). The room air stack affect is ignored since the inlet of the solar collector is designed at same level as the outlet of the cooling tube. Under the $5 \mathrm{~Pa}$ (0.020 inch of water) indoor outdoor pressure difference, the infiltration airflow is $0.03 \mathrm{~m}^{3} / \mathrm{s}$ (70 CFM). So the total chimney ventilation airflow is $0.15 \mathrm{~m}^{3} / \mathrm{s}$ (320 CFM).

The chimney height is selected as $10 \mathrm{~m}$ (33 feet) and the chimney diameter is selected as $0.457 \mathrm{~m}$ (18inch) with consideration of the cost and stability. The required chimney air temperature is $57^{\circ} \mathrm{C}\left(135^{\circ} \mathrm{F}\right)$ in order to generate a required available chimney draft of $5 \mathrm{~Pa}$ ( 0.020 inch of water). The design solar collector absorbing area is $20 \mathrm{~m}^{2}\left(215 \mathrm{ft}^{2}\right)$ if the design solar irradiation is $400 \mathrm{~W} / \mathrm{m}^{2}\left(126 \mathrm{Btu} / \mathrm{h} \cdot \mathrm{ft}^{2}\right)$ with an absorptance of 0.8 and a heat loss coefficient is $8.5 \mathrm{~W} /{ }^{\circ} \mathrm{C} \cdot \mathrm{m}^{2}$ $\left(1.3 \mathrm{Btu} / \mathrm{h} \cdot{ }^{\mathrm{o}} \mathrm{F} \cdot \mathrm{ft}^{2}\right)$.

\section{EXPERIMENT AND RESULTS}

The solar collector was built using plywood and glass. Since the sun altitude angle is 64 degree in August in Omaha, Nebraska, the solar collector was placed at a 26 degree angle on the south side of building in order to be oriented to the sun and receive the maximum solar radiation.

The chimney is a steel spiral pipe with a diameter of $0.4572 \mathrm{~m}$ (18 inches) and consists of three $3 \mathrm{~m}$ (10 feet) long sections. The chimney is placed on a $1.5 \mathrm{~m}$ ( 5 feet) high stand which is bolted to a concrete foundation. The foundation is 
about $1 \mathrm{~m}$ ( 3 feet) deep and contains about $3 \mathrm{~m}^{3}$ ( 3 cubic yards) of concrete. In order to give the chimney extra stability, 9 guy wires ( 3 on every section) were attached.

The solar collector is connected to the building and the chimney via of $0.4572 \mathrm{~m}$ (18 inches) diameter spiral pipe (same material as the chimney). The length of the connection pieces are $2.8 \mathrm{~m}$ (110 inches) between Solar Site and collector and $2 \mathrm{~m}$ (84 inches) between the collector and the chimney. The opening for the collector inlet is on the bottom of the collector. The opening for the collector outlet is on the top of the opposite site from the collector in order to use the positive stack affect in collector.

Temperature sensors were installed along the cooling tube, the collector and the chimney as well as in the room and the outside.

System operating parameters were measured from August 1, 2003 to August 9, 2003. During measurement one VELOCICALC ${ }^{\circledR}$ PLUS meter were installed inside the outlet duct of the cooling tube to measure the cooling tube airflow during the measurement.

Figure 2 compares the ambient temperature and the average chimney temperature measured by the temperature sensors. Both of them followed the changing solar radiation based on the time of day. The chimney air temperature reached up to $55^{\circ} \mathrm{C}\left(131^{\circ} \mathrm{F}\right)$ in afternoon due to high solar radiation when the outside air reached to $31^{\circ} \mathrm{C}\left(88^{\circ} \mathrm{F}\right)$. On the other hand, the chimney air dropped down to the ambient air temperature during night. The temperature difference between the chimney air and ambient air generated the draft required by the cooling tube system and sucked the warm outside air through the cooling tube during daytime.

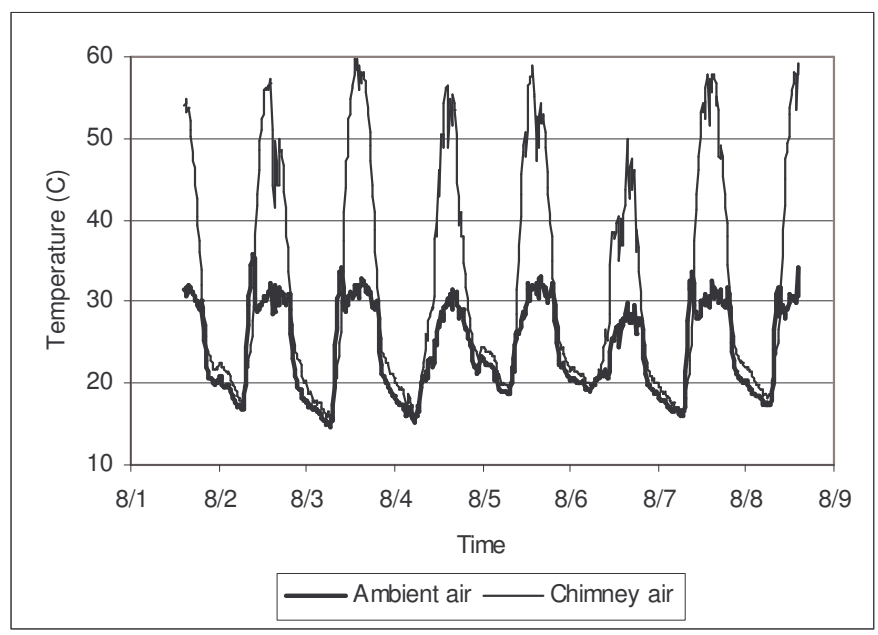

Figure 2: Measured ambient air temperature and average chimney air temperature

Figure 3 shows the cooling tube airflow and supply air temperature. The airflow pattern followed the temperature difference between the chimney air and the ambient air. The airflow reached to $0.13 \mathrm{~m}^{3} / \mathrm{s}$ (270CFM) in afternoon and the tube air temperature dropped down to about $16{ }^{\circ} \mathrm{C}\left(61{ }^{\circ} \mathrm{F}\right)$. The airflow dropped down to zero during night due to the zero chimney draft and the cooling tube outlet temperature has a same temperature as the indoor air.

Figure 3 also shows abnormal airflow patterns in the early morning of August 5 and in the afternoon of August 6. It was found that there was a strong south wind in the early morning of August 5 and the sky condition was between scattered and overcast in the day time of August 6 in this area. It demonstrates that the solar chimney system is sensitive to the whether condition, such as the wind and sky condition.

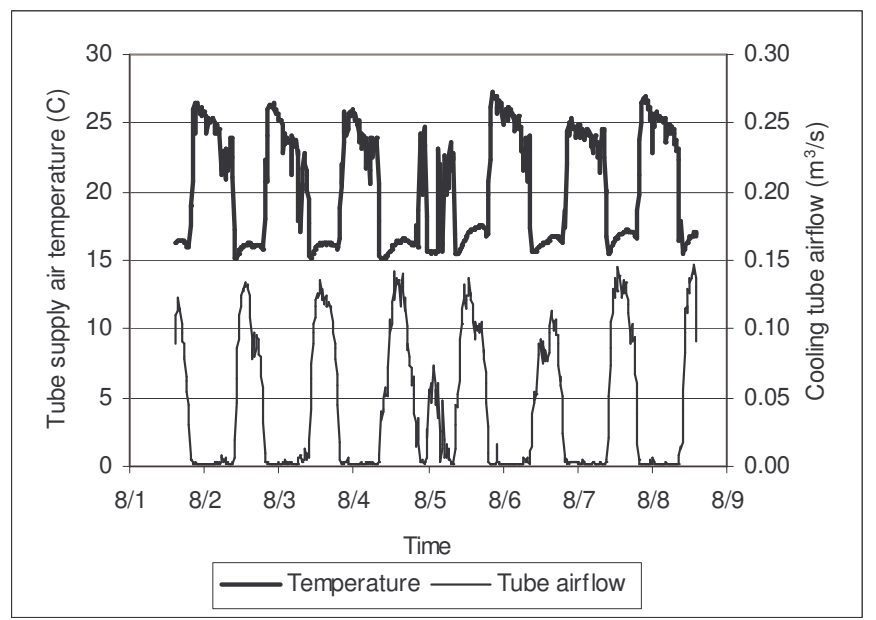

Figure 3: Measured cooling tube airflow and supply air temperature

Figure 4 compares the indoor air temperature and the ambient air temperature during the measurement. The room temperature was below $28{ }^{\circ} \mathrm{C}\left(82{ }^{\circ} \mathrm{F}\right)$ in afternoon when the ambient air reached to $31^{\circ} \mathrm{C}\left(88^{\circ} \mathrm{F}\right)$. The system cooing capacity can be obtained from the temperature different between the cooling tube supply air and the ambient air or the room air.

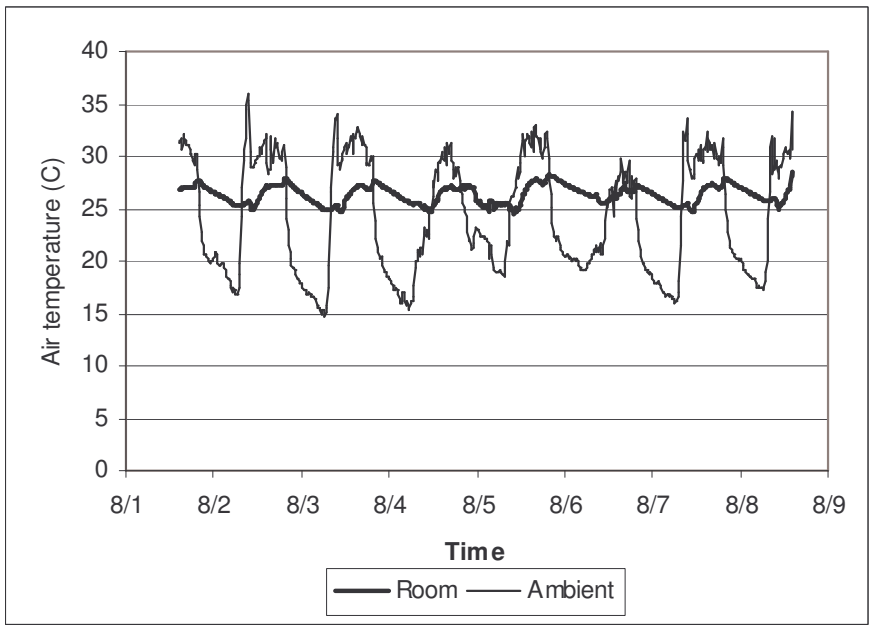

Figure 4: Measured room and ambient air temperature 
The outside air is cooled down by rejecting heat to the soil through the cooling tube and then the cold tube air is warmed up by absorbing heat from the room. The sensible cold from the soil to the tube air and the sensible cold from the tube air to the room can be easily calculated from air enthalpy change through the tube and the room. Figure 5 shows the calculated cooling tube sensible cold gain and supply. The cooling tube and solar chimney system in the test facility has a highest sensible cold gain of $2.4 \mathrm{~kW}(8,000 \mathrm{Btu} / \mathrm{h})$ from the soil and a highest sensible cold supply of $1.9 \mathrm{~kW}(6,500 \mathrm{Btu} / \mathrm{h})$ to the space. It also can be seen that the system can not provide a stable cold supply to the building. However, it has the highest cooling capacity when the building has the high cooling load in afternoon.

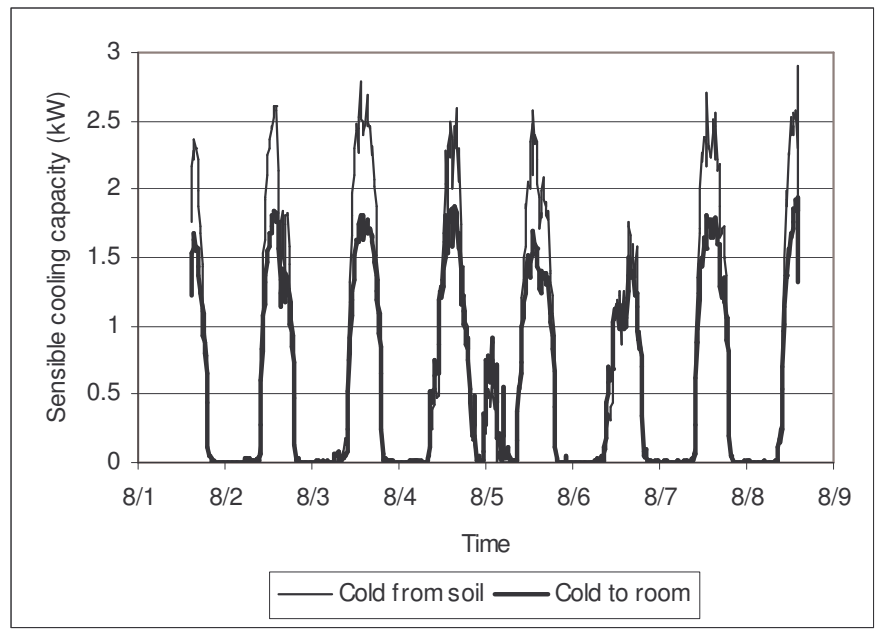

Figure 5: Cooling tube cold gain from soil and cold supply to building

The system airflow model is verified using the measured system operating parameters. Since solar radiation was not measured, the measured chimney air temperature is directly used in the airflow simulation instead of the solar collector heat balance equation. Figure 6 compares the measured airflows and the simulated airflows in August 6 and August 7, 2003. The simulated airflow matched the measured airflow well.

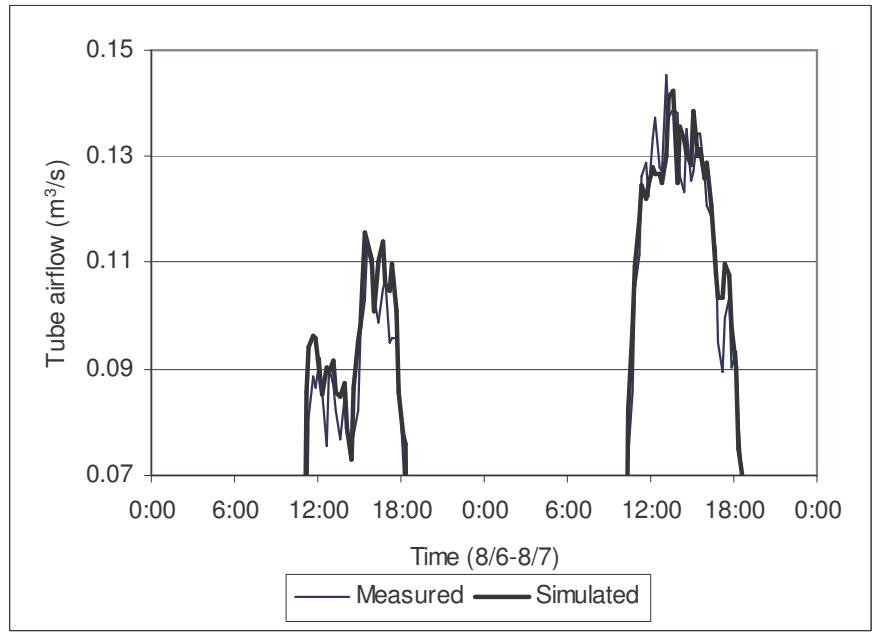

Figure 6: Comparison of measured and simulated airflow

\section{IMPROVEMENTS ON SYSTEM PERFORMANCE}

The test facility has a high air exchange rate, $2.25 \mathrm{ACH}$. It results in high infiltration airflow and low cooling tube airflow. Figure 7 compares the simulated total or chimney airflow and cooling tube airflow in two days. About $20 \%$ of chimney air flow did not pass through the cooling tube. The high air infiltration rate does not only reduce the cooling tube cooling capacity but also increase the building cooling load.

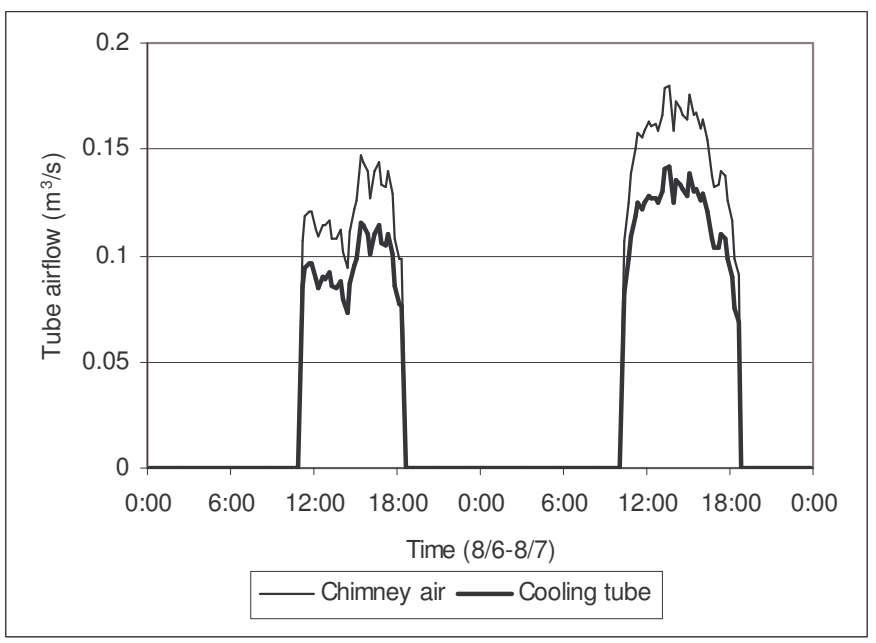

Figure 7: Simulated chimney and cooling tube airflows

In order to improve system performance, the building envelope should be tightened. If the test facility air infiltration rate is reduced to a lower level, the tube airflow will increase. Figure 8 shows the simulated improved tube airflow by tightening envelope to reduce air infiltration from $2.25 \mathrm{ACH}$ to $0.2 \mathrm{ACH}$. The cooling tube airflow increases by $10 \%$.

The actual solar radiation used in simulation is obtained from the measured chimney air temperature and room air temperature. It is also assumed the room temperature and cooling tube are not affected by the airflow change.

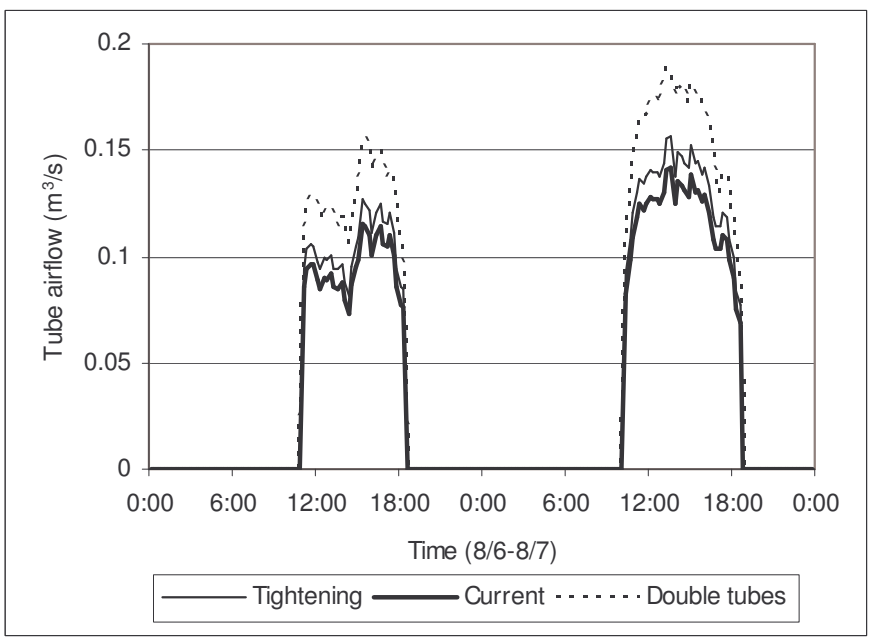

Figure 8: Improvement of cooling tube airflow 
On the other hand, the cooling tube resistance is another main factor for the system airflow. The longer cooling tube limits the airflow increase. For same cooling tube heat transfer area, two short parallel tubes can be installed instead of one long tube. Figure 8 also shows the simulated airflow of two parallel cooling tubes after tightening envelope. The cooling tube airflow will increase by $25 \%$ by these two improvements.

\section{CONCLUSIONS}

The airflow model of the solar chimney in the cooling tube and solar chimney system has been developed. The solar chimney design procedure has been developed for solar collector and chimney. One solar chimney has been designed. One solar collector with an absorbing area of $20 \mathrm{~m}^{2}\left(215 \mathrm{ft}^{2}\right)$ and one chimney with diameter of $0.457 \mathrm{~m}$ (18 inch) and height of $10 \mathrm{~m}$ (30 feet) were installed. The actual cooling tube airflow is measured to be $0.13 \mathrm{~m}^{3} / \mathrm{s}$ (or 270CFM) and the measured airflow matches the simulation results. The integrated system can obtain $2.4 \mathrm{~kW}(8,000 \mathrm{But} / \mathrm{h})$ peak cooling capacity from underground and supply $1.9 \mathrm{~kW}(6,500 \mathrm{Btu} / \mathrm{h})$ peak cooling energy to the space in afternoon. The tightened envelope and paralleled tubes can increase the system airflow by $25 \%$.

\section{REFERENCES}

1. ASHRAE handbook, HVAC Applications, Residences, pp. 1.1-1.4, American Society of Heating, Refrigerating and Air-conditioning Engineers, Inc., Atlanta, GA, 2000

2. ASHRAE handbook, HVAC Applications, Geothermal energy, pp. 31.18-31.20, American Society of Heating,
Refrigerating and Air-conditioning Engineers, Inc., Atlanta, GA, 2000

3. ASHRAE handbook, Fundamentals, Climatic Design Information, pp. 27.3-27.15, American Society of Heating, Refrigerating and Air-conditioning Engineers, Inc., Atlanta, GA, 2000

4. Mark A. Newman, M. Wang "ANALYSIS OF THE PERFORMANCE OF EARTH CONTACT COOLING TUBES", A Senior Project, University of Nebraska, June 1983

5. Chen, B., T. Wang, J. Maloney, J. Ennenga, and M. Newman. Measured Cooling Performance of Earth Contact Cooling Tubes. Proceedings of the American Solar Energy Society, Minneapolis, MN, 1983.

6. ASHRAE handbook, HVAC Applications, Solar Energy Use, pp. 32.1-32.12, American Society of Heating, Refrigerating and Air-conditioning Engineers, Inc., Atlanta, GA, 2000

7. D. S. Halacy, Jr., 1973. The Coming Age of Solar Energy, Harper \& Row, Publisher, Inc., New York

8. ASHRAE handbook, HVAC Systems and Equipment, Chimney, Gas Vent, and Fireplace Systems, pp. 30.1-30.11, American Society of Heating, Refrigerating and Airconditioning Engineers, Inc., Atlanta, GA, 2000

9. ASHRAE handbook, Fundamentals, Duct design, pp. 34.1-34.6, American Society of Heating, Refrigerating and Airconditioning Engineers, Inc., Atlanta, GA, 2000

10. ASHRAE handbook, Fundamentals, Ventilation and infiltration, pp. 26.1-26.12,American Society of Heating, Refrigerating and Air-conditioning Engineers, Inc., Atlanta, GA, 2000 